\title{
A Comparative Analysis of Profit Efficiency in Maize and Cowpea Production in the Ejura Sekyedumase District of the Ashanti Region, Ghana
}

\author{
Isaac Gershon Kodwo Ansah ${ }^{1, *}$, Hayford Oduro ${ }^{1} \&$ Awuah Lartey Osae ${ }^{1}$ \\ ${ }^{1}$ Department of Agricultural and Resource Economics, Faculty of Agribusiness and \\ Communication Sciences, University for Development Studies, Post Office Box TL 1882, \\ Tamale, Ghana \\ *Corresponding author: Department of Agricultural and Resource Economics, Faculty of \\ Agribusiness and Communication Sciences, University for Development Studies, Post Office \\ Box TL 1882, Tamale, Ghana. E-mail: agershon@uds.edu.gh
}

Received: September 17, 2014 Accepted: October 14, 2014 Published: December 22, 2014

doi:10.5296/rae.v6i4.6320 URL: http://dx.doi.org/10.5296/rae.v6i4.6320

\begin{abstract}
Resource allocation influences productivity or profitability of crop enterprises, particularly among smallholder agricultural systems, yet many empirical studies tend to ignore this fact. In this paper, we use profit efficiency measurement as a proxy for comparative advantage to decide the crop for specialization in the Ejura-Sekyedumase District in the Ashanti Region of Ghana. Using farm level data from 199 respondents who cultivate maize and cowpea, we employ the stochastic frontier function to measure and compare the profit efficiencies of farmers cultivating the two crops. Results from the analysis showed that the profit efficiency of maize farmers ranges between $47 \%$ and $96.7 \%$ while that of cowpea farmers ranges between $50.3 \%$ and $100 \%$ with mean profit efficiencies of $89 \%$ and $95 \%$ for maize and cowpea respectively. The study further showed that education, farm size and on-farm labour participation were major significant factors which influences profit efficiency in the study area. Farmers in Ejura-Sekyedumase stand to gain improvements in household welfare if available land and other scarce resources are allocated to cowpea agribusiness.
\end{abstract}

Keywords: Cowpea; Ejura-Sekyedumase; Ghana; Maize; Profit efficiency; Resource allocation 


\section{Background}

Agricultural productivity and efficient use of scarce natural resources such as agricultural land and variable inputs remain an important focus of government policies in sub-Saharan Africa. This sustainability objective of governments is even more central in recent times where population pressure and increasing urbanization are continuously generating a decline in agricultural land (Chamberlin et al, 2014; Nin-Pratt \& McBride, 2014; Kropff et al, 2013; Alene et al, 2006). In Ghana, the second Food and Agricultural Sector Development Programme (FASDEP II) policy agenda of the Ministry of Food and Agriculture (MoFA) which aims at modernizing agriculture to ensure food self-sufficiency on sustainable basis has one of its core themes to promote production of specific commodities in specialized zones within the country. A comprehensive strategy set up in this policy agenda is to focus on developing at most five staple crops, including maize, rice, cassava, yam and cowpea. The choice of crop would depend not only on the comparative advantage of producing the crop but also, the importance of the crop to the people in the specific zone as well as market availability. In line with the government objective of sustainable land and environmental management, efficient resource (land) allocation is crucial. Efficiency increases productivity, which can be achieved by avoiding misallocation of scarce resources. The low productivity arising from misallocation of resources robs farmers from making meaningful livelihoods. Recognizing the prominence that the government of Ghana ascribes to staple crops, and the fact that maize and cowpea form the primary recipients of many policy interventions in the cereal and leguminous classes respectively, this study focusses on the two crops. These crops have competitive advantages in terms of exports to the West-African sub-region, resulting in their positive net exports.

The Ejura-Sekyedumase district in Ashanti region of Ghana is a major production zone for maize and cowpea, with monocropping being the predominant system of farming used in the cultivation of these crops. Monocropping, as a system of farming, involves the allocation and cultivation of a farm or a plot of land to only one crop throughout a given cropping or farming season. Usually, cowpea and maize are two of the staple crops that compete for the same piece of land among farmers in the district. The choice of crop is typically dictated by the profit orientation of the farm family, where higher returns relative to the cost invested are the major factors driving this choice.

The policy objective of the Ghana government for the cowpea crop is to encourage increased production so that self-sufficiency can be achieved. According to the Food Balance Sheet of 2009 and 2010, the gross biological production of cowpea in Ghana stood at 205,000 Mt, but the available domestic production for human consumption was only 174,250 Mt from which the per capita consumption was $5.0 \mathrm{~kg}$ (SRID, 2010). The achievable yield of cowpea under rain-fed conditions in Ghana stands at $1.96 \mathrm{mt} / \mathrm{ha}$, but the countrywide average yield currently produced is $1.3 \mathrm{mt} / \mathrm{ha}$. In the study district the current average yield is estimated to be $1.02 \mathrm{mt} / \mathrm{ha}$. This leaves a yield gap, the causes of which must be investigated and remedied to achieve efficiency in resource use. Maize is also grown across the length and breadth of Ghana, but the bulk of it is cultivated in the Ejura-Sekyedumase ditrict. Currently, the national average maize yield is estimated at 1.6 tonnes per hectare, but with improved 
technologies yields of 4-5 tonnes per hectare have been recorded in on-farm demonstration fields. Since maize and cowpea have competitive advantages in the export market in West Africa, and considering their roles played as strategic crops for ensuring food security, it is important that options for increasing the availability of these crops through domestic production are unearthed. Despite the economic role played by the farmers in the Ejura-Sekyedumase district, very little is known about the efficiency performance of their maize and cowpea enterprises. Few studies (Anthony \& Ferroni, 2012) have attempted to understand the performance of smallholder farms and their approaches have concentrated on partial productivity measures such as output per unit area.

Empirical evidence suggests that improving the productivity of smallholder farmers is important for economic development because smallholder farming is a major source of employment and leads to a more equitable distribution of income (Bravo-Ureta \& Evenson, 1994). Bill Gates puts it better as follows: "Helping small, poor farmers achieve better yields for their own consumption and to sell at local markets is the most powerful way of combating hunger and poverty around the world" (Kropff et al., 2013). Accordingly, many researchers and policymakers have advocated the adoption of improved technologies as the sole source of increasing farm productivity and household income (Asfaw et al, 2013; WDR, 2008; Fan et al, 2005; Renkow \& Byerlee, 2010). This notion is premised on what we term the 'one size fits all' axiom whereby resources, particularly lands in different geographical locations, are assumed to be homogeneous and therefore expected to equally support any form of production. But differences in climate, resource endowment and quality as well as labour productivity all influence output, and hence efficiency. Failing to use resources efficiently leads to overexploitation and hampers sustainability. In this light, we argue that increasing farm productivity may not only result from improved technology use but also in resource allocation (Cunguara \& Darnhpfer, 2011). Moreover, all scarce resources are limited and have alternative uses; therefore it is important to allocate a given resource to the best possible use and not just attaining efficiency in the use of that particular resource. One fact about smallholder farming is the possibility to misallocate resources, resulting in inefficient production. Unfortunately many empirical studies in resource use efficiency and sustainability have overlooked this conception. In this paper, we define resource misallocation as failure to allot a given (scarce) factor of production to the most efficient and conservative use. For example, if a piece of land could produce cowpea more efficiently than maize but the farm firm cultivates the land to maize, we refer to it as resource misallocation. Resource misallocation has long-run implications not only on household welfare but also on gross domestic product and national food security. The best allocation of resources is a precondition for maximum household welfare, sustainable land use and food security.

The concept of comparative advantage is well-known but its application has usually been limited to the macro-level. Many empirical studies examine comparative advantage between countries in the production of given crops for export to international markets. Within a particular country, however, little attention is given to comparative advantage among competing enterprises in different agricultural zones. At the regional level within a country, efficiency in enterprise specialization can be equated to comparative advantage, particularly 
where a choice can be made between two or more competing enterprises. Just as trade between countries can be explained by differences in resources, within any country regional differences in resources should be a good guide to the choice of crop for specialization. ECOWAS recently signed the Economic Partnership Agreement with EU, which means that with time all tariffs will be waived on tradable food commodities. Thus, it is important for African governments to position themselves to benefit from such a policy by taking full advantage of comparative regional and zonal advantages in food production. A first step to achieving this aim is to examine the comparative advantages of crop at zonal levels. Comparative advantage advocates resources to be allocated to the most efficient enterprises. This notion is explicitly expressed in the Medium Term Agricultural Sector Improvement Programme (METASIP) of MoFA, Ghana.

Empirical studies in efficiency on crop production in Africa are skewed towards technical efficiency estimation (Ajibefun, 2003; Raphael, 2008; Ojo, 2004). The usual crops under consideration have been the cereals, with little research on the leguminous crops. In Ghana existing literature on efficiency measurements in maize has exclusively focused on output technical efficiency on individual crops (Abdulai et al., 2013; Sienso et al., 2014; Ofori-Bah $\&$ Asafu-Adjaye, 2011). Such studies tend to ignore the scarce nature of productive resources, particularly agricultural land, and the possibility that same resources could be allocated to alternative crop enterprises. Udry et al. (1995) stressed that significant improvement in efficiency could be attained by reallocating resources across plots of land. Again, as far as empirical literature in the Ghanaian context is concerned there are virtually no measurements on efficiency in cowpea production. To the best of our knowledge there is no empirical work that compares the efficiency of two competitive crops and to assess the best allocation of scarce resources based on economic efficiency, particularly in the Ghanaian context.

Studies identify a number of factors that influence the productivity and efficiency of producers under varying conditions, which are usually grouped under conventional and non-conventional factors. Conventional factors include those elements of production within farmer's control in their production decision process, while non-conventional factors capture the impacts of macroeconomic variables such as public investment and agro-ecological variables. Abdulai et al (2013) examined the technical efficiency of maize production in Northern Ghana, and established that the major determinants of maize output were farm size, seeds, fertilizer and weedicides. They estimated the mean technical efficiency for maize in the study area to be $74 \%$ and three key variables responsible for differences in technical efficiency among the maize farmers were mechanization, experience and gender. Binam et al (2004) also estimated a mean technical efficiency of $73 \%$ in Cameroun in a study that aimed at assessing the factors influencing technical efficiency among smallholder farmers in slash and burn agriculture. They identified credit accessibility, social capital, soil fertility and distance to access roads and extension services as key determinants of efficiency. Deininger \& Olinto (2001) and Pender et al. (2004) identified fertilizer, livestock ownership, access to credit, supply of extension, human capital (education, age, and gender of household head), family size and proportions of dependents as explanatory variables to efficiency. The findings showed that ownership of livestock, primary sources of income, age of household head, 
ownership of land and participation in agricultural extension activities positively affected productivity.

The effect of farm size on productivity and efficiency has received much attention in empirical literature where bulk of the studies identifies an inverse relationship between farm size and productivity (Barrett, 2010; Helfand \& Levine, 2004; Manjunatha et al, 2013; Latruffe \& Piet, 2014; Alvarez \& Arias, 2004; Collier, 1983). Barret (2010) aimed to explain possible causes of the inverse relationship which stands in sharp contrast to economic theory, and noted that about one-third of the noise due to imperfect markets explains the significant inverse relationship between farm size and productivity. In Uganda, Pender et al (2004) showed that farm size was negatively related to productivity such that small farms are more efficient than larger farms. Frisvold \& Ingram (1995) also agree that for small fields output is normally small but in terms of productivity they perform better than larger plots. Manjunatha et al (2013) explained that the efficiency of small farms is due to the fact that owners of such farms use resources more efficiently. Farm level factors such as farm size, land tenure, distance of the field from the residence affect productivity (Xu et al., 2009). Again, access to both local and export markets are likely to have positive influence on productivity as well as efficiency because available market tends to absorb any quantity produced.

This paper has two points of focus. First, it contributes to the efficiency literature and supports the calls for sustainability by comparing the profit efficiency of maize and cowpea enterprises. Second, it reemphasizes the need to reallocate resources among crop enterprises to ensure sustainability and to take full advantage of regional or zonal comparative advantage, particularly where the crops concerned compete for same resources. Farmers normally allocate resources in response to price incentives, and several factors could play significant roles in determining the profits of crop enterprises, whereby given the same piece of land with similar characteristics, there could be differences in productivity due to several factors. What are these factors? Our main objective for this research therefore, is to identify which of the two crops is profit efficient and to examine factors that are responsible for the differences in profit efficiency among farmers. Knowledge in this direction is necessary for optimum farm household and agribusiness firm decision-making, to serve as a guide to land use policy making and help Ghana government focus on interventions to render to specific crops in specific agricultural zones.

\section{Methods}

\subsection{Analytical framework}

Every rational and commercially-oriented farm firm aims at profit maximization; even the non-commercial farmer's intention of producing is to obtain the maximum achievable output from the available resources. The classical approach used to examine such technical relationship linking input transformation into outputs is the production function, from which technical inefficiency in production could easily be determined. A farmer is said to be technically inefficient if, given a certain amount of (scarce) resources, the actual level of 
production falls below the theoretical maximum, as defined by the production frontier (Tsionas \& Kumbhakar, 2004). The concept of technical efficiency measurement among smallholder farmers has some limitations, especially in situations where farmers with different resource endowments and facing different prices are considered, as it is typical of the Ghanaian setting (Ali \& Flinn, 1989). Rehman (1982) posits that assessing productivity of farmers based on technical efficiency criteria alone tends to ignore other economic goals of decision making units (DMU). He further stipulates that technical efficiency only answers the question of how to produce but does little to adequately address the issue of how much to produce. Therefore, a farmer trying to achieve technically efficient production level could be at variance with profit maximization objective, and this represents a cost not only to the individual farmer but a social welfare loss. Moreover, studies that rely solely on technical efficiency as a measure of productivity have received many criticisms. It is argued that input levels are often endogenous and that estimating a profit or cost function in lieu of production function avoids the endogeneity bias (Adesina \& Djato, 1997; Quisumbing, 1994). As outlined by Berger \& Mester (1997) and Coelli et al (1998; p. 209), the broader concept of economic efficiency such as the profit efficiency is a more acceptable approach to measuring efficiency under these conditions. They argue that farmers operate based on economic optimization in response to market prices and competition, rather than being based solely on technology. Further, Berger and Mester (1997) outlines that profit efficiency is able to capture errors both on the output and input sides of the production process. According to Ali et al (1994), the profit function approach combines the concepts of technical and allocative efficiency in the profit relationship and any error in the production decision is assumed to be translated into lower profits or revenue for the farmer. If the farmer fails to operate on the profit frontier, he/she is considered to be profit inefficient, otherwise it is profit efficient and is able to earn the maximum allowable profit from the available and given resources. Since the rate at which inputs are transformed into agricultural outputs varies among crops, soil types, land area, capital, agro-inputs, technologies, climatic conditions (rainfall and temperature levels) and labour, it also contributes to how feasible the production will generate profit at the end. Very limited studies in Africa have used the standard profit function to examine the efficiency of crop farmers. Examples include the study by Adesina and Djato (1996) who applied the technique in a study of efficiency of rice farmers in Cote d'Ivoire. Elsewhere in the world, the main applications of the profit frontier have been in the banking sector. We derive the profit frontier function as follows:

Given the level of output (y), the farmer aims at maximizing profit at minimum cost. Let the output price be denoted by $p$, the input price vector be denoted by $w$ and the level of quasi-fixed factors by $a$ (for our study, we focus on land), then the profits $(\pi)$ are maximized by adjusting levels of output $(y)$ and input $(x, a)$ quantities. Following the theory of the stochastic production function as proposed by Aigner et al (1977) and Meeusen \& Van den Broeck (1977), the stochastic profit function of farmer $i$ is expressed as

$$
\pi_{i}=f\left(p_{i}, w_{i}, a_{i}\right) \exp \left(v_{i}-u_{i}\right)
$$

While the frontier profit function is given by 


$$
\pi_{i}^{*}=f\left(p_{i}, w_{i}, a_{i}\right) \exp \left(v_{i}\right)
$$

The $v_{i}{ }^{\prime} s$ represent the idiosyncratic components which are independent and identically distributed random errors with mean zero and variance $\sigma_{v}^{2}$. The presence of $v_{i}$ is due to random factors that are usually beyond the control of the farmer such as climatic conditions and measurement errors. The $u_{i}{ }^{\prime} s$ are non-negative random variables that are associated with factors typical of individual farmers which prevents them from attaining the maximum profit specified by the frontier (Battese, 1992). The non-negative random variable is responsible for the profit inefficiency and has values that lie between 0 and 1 . The $u_{i}$ has a non-negative half-normal distribution. For the profit function, $u_{i}$ and $v_{i}$ are assumed to behave in a way consistent with the concept of stochastic frontier functions.

The profit efficiency (PE) of farmer $i$ is defined as the factor by which the level of profit for the farmer is less than its frontier profit (Battese, 1992). Given the stochastic profit frontier model as expressed by equation (1), the PE is calculated from equation (3)

$$
P E_{i}=\frac{\pi_{i}}{\pi_{i}^{*}}=\frac{f\left(p_{i}, w_{i}, z_{i}\right) \exp \left(v_{i}-u_{i}\right)}{f\left(p_{i}, w_{i}, z_{i}\right) \exp \left(v_{i}\right)}=\exp \left(-u_{i}\right)
$$

In measuring efficiency based on the stochastic profit frontier, two key assumptions are made which results in two types of the function. Depending on whether market forces are taken into account or not, the standard and the alternative profit functions can generally be recognized (Berger \&Mester, 1997). The standard profit function considers the profit gain from operating on the profit frontier, taking into consideration farm-specific prices and factors. It assumes that markets for outputs and inputs are perfectly competitive. Under the standard profit function, when given the input price $(w)$ and output price $(p)$ vectors, the enterprise maximizes profits by adjusting the amount of inputs and output. The standard profit function can be expressed implicitly by equation (4) and the logarithmic form by equation (5)

$$
\begin{gathered}
\pi=f(p, w, z ; v, u) \\
\ln (\pi+\theta)=\ln f(p, w, z)+(v-u)
\end{gathered}
$$

$\theta$ is a constant added to the profit of each farm to obtain positive values that can permit logarithmic transformation. The variance of the random errors $\sigma_{v}^{2}$ and that of the profit inefficiency effects $\sigma_{u}^{2}$ and overall variance of the model $\sigma^{2}$ are related by equation (6)

$$
\sigma^{2}=\sigma_{v}^{2}+\sigma_{u}^{2}
$$

which measures the total variance of profit from the frontier which can be attributed to profit inefficiency. Battese and Coelli (1995) estimated gamma $(\gamma)$ from the relation in equation (7) which quantifies the share of inefficiency in the overall residual variance. 


$$
\gamma=\frac{\sigma_{u}^{2}}{\sigma_{v}^{2}+\sigma_{u}^{2}}
$$

with $\quad 0 \leq \gamma \leq 1$

The implicit assumption in the equation specified in equation (5) is that no farmer has any market power. However, in most rural and smallholder settings, markets are undoubtedly imperfect and different farmers receive different prices depending on their bargaining power and negotiation skills. In this case, the quantity of output produced replaces the output price in the standard profit function, yielding the alternative profit function, proposed by Berger \& Mester (1997) and expressed in equation (8) and (9)

$$
\begin{gathered}
\pi_{\text {alt }}=\pi_{\text {alt }}(y, w, z ; v, u) \\
\ln \left(\pi_{\text {alt }}+\theta\right)=\ln \pi_{\text {alt }}(y, w, z)+(v-u)
\end{gathered}
$$

The alternative profit function explores how farmers are able to achieve the highest attainable profit conditional on their output levels rather than output prices (Ibid). The proponents indicate that the alternative profit function reduces scale bias that is often present in the standard profit function by holding outputs fixed and measuring farmers' ability to generate more profit.

\subsection{Empirical Model}

Following the work of Berger and Mester (1997), we adopt a (logarithmic) Cobb-Douglas functional form of the alternative profit efficiency model. In this model, output is held constant while output prices vary, expressed as in equation (10).

$$
\ln \pi_{i}=\alpha_{0}+\sum_{j=1}^{4} \alpha_{j} \ln w_{i}+b_{1} \ln y_{i}+b_{2} \ln a+\left(v_{i}-u_{i}\right)
$$

The reasons for our choice of this function include

- Output prices may not be measured accurately due to different measurement scales in typical rural Ghanaian markets.

- Differences in quality of labour may rather translate into different outputs realized by farmers. If output prices are used instead of output levels, it is likely that these differences in the quality of labour may remain unmeasured.

- Maize and cowpea output markets are not perfectly competitive in the Ejura-Sekyedumase district. As in most rural Africa, markets for crop produce are seasonal and prices that farmers receive depend on their negotiation power and skills with assemblers. Therefore, more produce can only be sold if prices are reduced, particularly during bumper harvests. Therefore, the alternative profit function is better fit to this situation than the standard profit function. 


\section{Macrothink}

The general Cobb-Douglas functional form of the alternative profit function specified for the crops in the study area is:

$$
\begin{gathered}
\ln \pi_{k}=\beta_{k 0}+\beta_{k 1} \ln w_{k}+\beta_{k 2} \ln w_{k}+\beta_{k 3} \ln w_{k}+\beta_{k 4} \ln w_{k}+\beta_{k 5} \ln y_{k}+\beta_{k 6} \ln a_{k}+(v-u)(11) \\
\mathrm{k}=1,2 \text { (1 = maize, } 2 \text { = cowpea) }
\end{gathered}
$$

where $w_{1}$ is average price per $\mathrm{kg}$ of seeds, $w_{2}$ is average price per $\mathrm{kg}$ of fertilizer or insecticide, $w_{3}$ is average wage rate, $w_{4}$ is average price per litre of weedicide, $y_{k}$ is level of output per $\mathrm{kg}$ and $a_{k}$ is the area cultivated to the particular crop (farm size). The profit inefficiency model for the two crops (maize and cowpea) is measured by equation (12) as follows

$$
\mu_{i}=\delta_{0}+\delta_{1} z_{1}+\delta_{2} z_{2}+\delta_{3} z_{3}+\delta_{4} z_{4}+\delta_{5} z_{5}+\delta_{6} z_{6}+\omega
$$

where $z_{1}=$ age, $z_{2}=$ educational status of farmer, $z_{3}=$ household size, $z_{4}=$ on-farm labour participation, $z_{5}=$ years of farming experience of the farmer and $z_{6}=$ total farm land holding. The description, measurement and a priori expectations of the variables are given in table 1 . The dependent variable $\mu_{i}$ is measuring profit inefficiency; hence a positive $\delta$ coefficient implies a negative influence on efficiency while a negative coefficient implies the variable positively influences efficiency.

Table 1. Descriptions, measurements and a priori expectation of variables used in the Stochastic Profit Frontier

\begin{tabular}{lllll}
\hline Variable & Description & Measurement & \multicolumn{2}{c}{ A priori Expectation } \\
\hline & & & Maize & Cowpea \\
& Profit function variables & & & \\
$w_{1}$ & Cost of seeds & $\mathrm{GHC} / \mathrm{kg}$ & - & - \\
$w_{2}$ & Cost of fertilizer & $\mathrm{GHC} / \mathrm{kg}$ & - & - \\
$w_{3}$ & Cost of labour (wage rate) & $\mathrm{GHC} / \mathrm{manday}$ & - & - \\
$w_{4}$ & Cost of weedicide & $\mathrm{GHC/litre}$ & - & - \\
$w_{5}$ & Cost of insecticide & $\mathrm{GHC} /$ litre & - & - \\
$y$ & Level of output & $\mathrm{kg}$ & + & + \\
$a$ & Total land & Acres & + & + \\
& Inefficiency variables & & & + \\
$z_{1}$ & Education & 1 if educated, 0 if none & + & + \\
$z_{2}$ & Age category of the farmer & years & + & + \\
$z_{3}$ & Farm size & acres & + & + \\
$z_{4}$ & Farmers' experience & years & + & + \\
$z_{5}$ & On-farm labour & people (count) & + \\
$z_{6}$ & Total farmland holding & acres & - & - \\
\hline
\end{tabular}




\subsection{Student t-test}

We used the student's t-test to examine whether there is a statistically significant difference in the profit efficiency of the two crops. This test statistic follows a Student's $t$ distribution if the null hypothesis is supported. The t- statistic, given by $t_{\text {score }}=\frac{\beta_{1}-\beta_{0}}{\operatorname{se}\left(\beta_{1}-\beta_{0}\right)}$ with (n-k) degrees of freedom, tests for significant difference in the means of the efficiency estimates for maize and cowpea. A statistically significant difference between the mean efficiencies would support our hypothesis that there should be crop specialization based on comparative advantage.

\subsection{Data and Descriptive Statistics}

Ejura-Sekyedumase district a major hub for the production and marketing of food staples, particularly maize and cowpea. It is located in the northern part of the Ashanti Region and covers a total land size of $1,782.25 \mathrm{sq} \mathrm{km}$, out of which $1,335 \mathrm{sq} . \mathrm{km}$ is arable. The district is bordered on the north by Nkroanza North and Atebubu-District of the Brong- Ahafo Region, to the East by Sekyere Central, to the south by Sekyere West and Mampong and to the west by Offinso North and Nkroanza South Districts. It lies within longitude $1.432^{\circ}$ west and latitude $7.375^{\circ}$ north. Farm level cross-sectional data were generated for the analysis using multi-stage sampling technique. In the first stage, 7 communities were randomly selected based on the district profile obtained from the district MoFA office. The communities selected include Ashakoko, Bisiw No.1, Bisiw No.2, Babaso, Ejura, Nokwareasa and Sekyedumase. The second stage involved a simple random selection of 50 farmers each from Ejura and Sekyedumase and the remaining 20 each from Ashakoko, Bisiw No. 1, Bisiw No. 2, Nokwareasa thus making 200 respondents, but questionnaire from one respondent was excluded from the analysis due to non-response. The selection was based on the geographical size of the towns. A structured questionnaire containing both closed and open-ended questions was used to interview farmers to solicit information inputs and output variables as well as household demographic factors and farm-specific characteristics such as the type of crops grown, the number of labourers employed on the farm, types of agro-inputs applied on the farm. The data collected (on quantity of maize and cowpea harvested and output prices) were used to compute total farm revenue using the formula $P \times Q$, where $P$ is price of the output and $Q$ is the quantity produced. Farm level profit $(\pi)$ was computed as the difference between the total revenue and total variable cost expended on producing the crop i.e. [Gross Margin $(\pi)=P Q-W X]$. Table 2 gives the summary statistics of the variables captured in the main profit function. The average profit earned from cowpea production was higher than that obtained from maize per acre. 
Table 2. Summary statistics of variables used in model estimation

\begin{tabular}{lllll}
\hline Variable & Maize & & Cowpea & \\
\hline Main model & Mean & Std. deviation & Mean & Std. deviation \\
\hline Profit/acre & 1174.06 & 1923.63 & 1480.95 & 2716.46 \\
Output & 28.31 & 28.53 & 20.55 & 83.36 \\
Farm size & 5.41 & 3.18 & 4.12 & 2.96 \\
Fertilizer cost & 16.04 & 12.48 & - & - \\
Herbicide cost & 3.05 & 2.38 & 8.98 & 0.19 \\
Labour cost & 15.21 & 11.88 & 57.52 & 8.03 \\
Seed cost & 6.56 & 4.28 & 178.64 & 139.57 \\
Insecticide cost & - & - & 14.76 & 0.80 \\
& & & & \\
Inefficiency model & & 11.9 & 2.5 & 0.90 \\
Age & 38.9 & 0.28 & 0.92 & 0.28 \\
Education & 0.91 & 5.47 & 7.99 & 6.04 \\
Household size & 7.32 & 11.76 & 16.42 & 11.95 \\
Experience & 15.65 & 4.84 & 6.84 & 4.37 \\
Farm size & 6.61 & 2.14 & 2.77 & 2.31 \\
On-farm labour & 2.59 & & & \\
\hline
\end{tabular}

\section{Results and Discussion}

\subsection{Brief Overview of the Demographic Characteristics of Farmers in the Survey}

Maize and cowpea production in the Ejura Sekyedumase is dominated by men (87.9\%) with very few women (12.1\%). The distribution of sex in our survey may be explained by the socio-cultural pattern of the study area where most women are involved in domestic and household chores, and do trading, dressmaking as well as activities in the services sector to support their husbands. This distribution, according to the respondents, helps diversify family sources of income. Few of the respondents were below age $20(3.0 \%)$ while respondents aging between 21 and 40 accounted for the majority (57.3\%). Approximately $40 \%$ of respondents aged above 40 years.

In the survey, $62.8 \%$ of the respondents had primary to tertiary education while the remaining $38.2 \%$ had no formal education at all. Through education, the quality of labour could be improved and the propensity to adopt new and improved farming techniques could increase (Hyuha, et al, 2006). Thus, farmers in the study area may easily adopt new technologies due to enhanced educational outlook of majority of the respondents. This could improve productivity and therefore level of profit earned from the respective enterprises 
Table 3. Demographic and Socio-economic Characteristics of Farmers

\begin{tabular}{llll}
\hline Variable & Category & Frequency & Percentage \\
\hline Education & No education & 76 & 38.2 \\
& Primary & 47 & 23.6 \\
MSLC/JSS & 56 & 28.1 \\
A/O Level/SHS & 17 & 8.5 \\
Tertiary & 3 & 1.5 \\
Sex & Male & 175 & 87.9 \\
Age group (years) & Female & 24 & 12.1 \\
& Below 20 & 6 & 3.0 \\
& $21-40$ & 114 & 57.3 \\
& $41-50$ & 45 & 22.6 \\
& $51-60$ & 23 & 11.6 \\
\hline
\end{tabular}

\subsection{Hypothesis tests and variance parameters}

The likelihood ratio test is used to assess the null hypothesis that there is no inefficiency factor in the farm profit function. The statistic, shown in table 2, rejects the null hypothesis of no profit inefficiency effect in the model, and supporting the alternate hypothesis that there is a significant inefficiency effect in the profit function. The variance ratio parameter (gamma) produced a value of 0.72 for the maize model and 0.80 for the cowpea model. These results imply that at least $72 \%$ and $80 \%$ of the differences between the observed and frontier profits for maize and cowpea respectively are due to existing differences in efficiency levels among the crop farmers. The estimated sigma squared $\left(\sigma^{2}\right)$ of 0.0596 for maize and 0.0408 for cowpea were all significant at $1 \%$ level of significance, indicating a good fit of the respective models (Rahman, 2003). The parameter estimates for the determinants of profit inefficiency are reported at the lower part of table 4.

Table 4. Estimated coefficients from the stochastic profit frontier model

\begin{tabular}{lclll}
\hline Crop & \multicolumn{2}{c}{ Maize } & \multicolumn{2}{c}{ Cowpea } \\
\hline Variable & Coefficient & Std. Error & Coefficient & Std. Error \\
\hline Main model & & & & \\
Output & $0.53^{* * *}$ & 0.027 & $1.48^{* * *}$ & 0.042 \\
Fertilizer & $-0.66^{* * *}$ & 0.229 & - & - \\
Herbicide & $0.64^{* * *}$ & 0.221 & -0.12 & 1.980 \\
Labour & $-0.06^{*}$ & 0.032 & $0.25^{* *}$ & 0.123 \\
Seeds & -0.07 & 0.092 & $-0.19^{* * *}$ & 0.067 \\
Insecticide & - & - & -0.18 & 0.348 \\
Farm size & $-0.16^{* *}$ & 0.074 & $-0.19^{* * *}$ & 0.067 \\
Constant & $8.16^{* * *}$ & 0.413 & 4.81 & 4.529 \\
\hline
\end{tabular}


Table 4. continued

\begin{tabular}{lllll}
\hline Inefficiency model & & & & \\
Age & 0.216 & 0.455 & 5.355 & 6.151 \\
Education & $0.264^{*}$ & 0.157 & - & - \\
Household size & -0.057 & 0.087 & -0.473 & 0.301 \\
On-farm labour & 0.023 & 0.170 & $0.528^{*}$ & 0.316 \\
Experience & -0.062 & 0.053 & 0.158 & 0.139 \\
Total land & $0.129^{* *}$ & 0.064 & $-0.763^{*}$ & 0.428 \\
Square of total land & - & - & $0.022^{*}$ & 0.011 \\
Household head & - & - & 22.23 & 2000 \\
Community & - & - & 0.378 & 0.495 \\
Model diagnostics (Variance parameters) & & & \\
Sigma squared & 0.0596 & 0.0127 & 0.0408 & 0.013 \\
Lambda & 1.2623 & 0.0533 & 2.0129 & 0.068 \\
Gamma & 0.717 & & 0.802 & \\
Log-likelihood function & $3.40^{* *}$ & & $1.73 *$ & \\
Mean profit efficiency & 0.866 & & 0.951 & \\
No. of observations & 124 & & 61 & \\
\hline
\end{tabular}

$*$, ** and $* * *$ indicates that coefficients are significant at $10 \%, 5 \%$ and $1 \%$ levels respectively

\subsection{Factors Influencing Profits and Efficiency in Maize and Cowpea Production}

The study identified key factors that influence the profit of maize and cowpea enterprises as well as efficiency of farms cultivating these crops under monocropping system. The results of the maximum likelihood estimates are presented in table 3. The direction of most of the input prices meet theoretical expectation, indicating that the average profit function of farmers in the study area is convex in input prices. Profit elasticities for all the variables are statistically significant for the maize crop except the price of seeds. In the case of the cowpea, only output, average prices of labour and seeds, and farm size are statistically significant. According to the farmers, inorganic fertilizers are not used in cowpea production; instead insecticides are very much necessary, especially during the flowering stage to control insect pests. Cowpea, being a leguminous crop, is able to fix atmospheric nitrogen through the symbiotic association with the Rhizobium bacteria. Therefore, additional inorganic fertilizer application would be superfluous and may enrich the soil to the extent that vegetative growth of the crop is facilitated rather than flowering and fruiting. It is therefore reasonable and follows scientific logic that inorganic fertilizers are not used at all in cowpea production. This also helps farmers to save some costs or channel moneys meant for inorganic fertilizer into other yield enhancing investments. The directions of the elasticity coefficients for output and farm size, as well as all the price variables meet apriori expectation, except for price of herbicides for the maize crop. We expected an inverse relationship of herbicide cost with profit, but our a priori expectation was not met. What we observed rather implies that higher costs of 
herbicides lead to higher levels of profit. Even though this outcome is against intuition, it is plausible. In the Ghanaian herbicide input market, variety of the active ingredients are available, containing both counterfeit and original products. While the imitated products are cheap, the original and very potent ones are quite expensive, and the cost increases with potency. Because of the efficacy of the active ingredients such costly herbicides are able to control weeds well and as a consequence better yields are obtained which may translate into higher profits, ceteris paribus. The policy lesson that can be learnt from these results calls for governments to screen and set standards to regulate the trade in agrochemical products. This would ensure that ignorant farmers are not exploited by unscrupulous input traders and agricultural production is not stifled.

The inefficiency models produced fairly expected results. Surprisingly, not many factors that were captured in our models significantly explain the variation in efficiency among farmers in both crop enterprises. This means that there aren't many factors that generate differences in efficiency among the farmers in the study area, and may be an indication that farmer characteristics are fairly homogeneous. In the profit efficiency model for maize, only education and total land assets explain differences in efficiency. According to our results, there is a statistically significant inverse relationship between education and efficiency. Farmers with formal education are less profit efficient than farmers without formal education. Again, this is counterintuitive, yet a possibility and a number of explanations can hold. First, farmers without formal education may have limited off-farm jobs; hence maximum attention is given to the care and maintenance of the farm enterprise. With limited job opportunities uneducated may only use the cheapest available techniques and inputs that can produce the maximum profit from each enterprise. Second, it is not out of place to say that educated people are often quick to use modern agricultural techniques which usually require additional financial outlay. Hence, even though educated people may be technically efficient, they fail to maximize profit or achieve economic efficiency. This further stresses the importance of using economic efficiency to assess performance instead of using only technical efficiency. The findings from the maize inefficiency analysis brings to the fore the need to examine the real impact of formal education in productivity analysis. It may be the case that for smallholder farming, what matters most is (arguably) custom-made training to farmers rather than formal education.

In the efficiency model for cowpea, we found only the number of people working on the farm and farm size to statistically influence profit efficiency at $10 \%$ level of significance. On-farm labour participation is inversely related to profit efficiency, so the larger the number of people working on the farm, the lower the efficiency, which is quite unexpected. One could reason that, cowpea can serve as a cover crop; hence less labour is needed to control weeds and undertake other major activities on the farm. Therefore, more people only tend to increase cost per acre and so reduce efficiency.

In conformity with empirical studies by Manjunatha et al (2013) among others, small-sized farms (in both maize and cowpea) are more profit efficient than larger farms. Small farm owners usually devote much time for maintenance and care because farming is their main business and primary source of income. Hence, they do all within their power to ensure that 
maximum profits are obtained from their farm businesses.

\subsection{Comparative analysis of profit efficiency in maize and cowpea farms}

The mean efficiency scores (95\%) for cowpea farms are significantly different from that of maize $(89 \%)$ farms as indicated in table 5 . Thus, while cowpea farmers are only 5\% inefficient in maximizing profit, maize farmers are $14 \%$ inefficient below the frontier profit. The hypothesis to test whether the profit efficiencies of maize and cowpea are equal was carried out using the t-test as described in section 3.5.4. The t-statistic produced a score of 5.0112 with a p-value of 0.000 , which is statistically significant at $1 \%$ level (see table 5 below). This means that the profit efficiency of cowpea farmers is statistically higher than that of maize farmers.

Table 5. Students' t-test for profit efficiency between maize and cowpea farms

\begin{tabular}{llll}
\hline Profit efficiency & Observations & Mean & Std. error \\
\hline Maize & 124 & 0.8900216 & 0.0068034 \\
Cowpea & 61 & 0.9509292 & 0.010446 \\
Combined & 185 & 0.9101047 & 0.0060768 \\
Difference & & 0.0609076 & 0.0121543 \\
t-value & 5.0112 & & \\
p-value $(\mathrm{T}>\mathrm{t})$ & 0.000 & & \\
\hline
\end{tabular}

This result indicates that there are gains to be made in efficiency improvement by reallocating resources, particularly land, from maize to cowpea production within the same locality in the district. At the national level, what this means is that the Ejura-Sekyedumase district has a comparative advantage in cowpea production. As outlined in the policy document of Ghana government, the concept of using comparative advantage among other indicators as a basis for crop specialization in specific zones within the country is a laudable idea. Truly, specific crops can perform better economically in different agro ecological zones. Therefore, the first important objective is to ascertain which crops best suit which agro ecological zones in efforts to ensure that efficient utilization of limited resources are achieved. With the limited resources used efficiently, the widely held concept of sustainability would be earnestly pursued.

\section{Conclusions and Recommendations}

The study sought to measure the profit efficiency and examine factors that influence efficiency of maize and cowpea production in the Ejura-Sekyedumase district in the Ashanti region of Ghana. We used data collected from 199 farmers sampled from the study area for analysis. The results showed that

1. Profits, and for that matter productivity of both maize and cowpea are significantly determined by the direct or conventional production factors such as cost of seeds, agro-chemicals, farm size and level of output. 
2. Profit efficiency in maize is influenced by such factors as education and farm size while that of cowpea is influenced by on-farm labour participation and farm-size. With regards to farm size, larger farms are less profit efficient than small farms.

3. Cowpea production is significantly more profitable than maize production. This generates lower efficiency levels for maize farmers compared to cowpea farmers.

On account of the above the following recommendations are established.

1. In conformity with Ghana government's objective of promoting staple crop production in specific zones based on comparative advantage, we recommend that farmers in the Ejura-Sekyedumase district would be better off if they specialize in cowpea production. If the government's effort requires special support to farmers, then on efficiency grounds, social welfare would be increased if such support programmes concentrate on cowpea production. This said however, resource use efficiency is often not the only objective of governments, and one can equally argue that maize is a strategic staple crop, with many poor people depending directly on it for food and livelihood. Therefore, the absolute implementation of this recommendation depends also on the discretion and the overarching policy objective of the government.

2. Farmers are advised to assign fewer people to work on cowpea farms since more people working on a given land area tends to reduce efficiency. Again, if land redistribution is possible, we recommend that larger farms should be redistributed to cover more smallholder farmers which have the potential to reduce poverty.

3. The fact that in maize production formal education reduces efficiency provides the basis for further research into the real impact of education in productivity analysis. It is important to examine whether formal education is really responsible for productivity or that custom-made training (such as on-farm demonstration on improved techniques) to farmers that enhances productivity.

\section{References}

Abdulai, S., Nkegbe P. K., \& Donkoh S. A. (2013). Technical efficiency of maize production in Northern Ghana. African Journal of Agricultural Research, 8(43), 5251-5259

Adesina, A. A., \& Djato, K. K. (1996). Farm size, relative efficiency and agrarian policy in Côte d'Ivoire: profit function analysis of rice farms. Agricultural Economics, 14(2), 93-102. http://dx.doi.org/10.1016/0169-5150(96)01181-4

Adesina, A. A., \& Djato, K. K. (1997). Relative efficiency of women as farm managers: Profit function analysis in Côte d'Ivoire. Agricultural Economics, 16(1), 47-53. http://dx.doi.org/10.1016/S0169-5150(96)01212-1

Aigner, D., Lovell, C. A. K, \& Schmidt, P. (1977). Formulation and estimation of stochastic frontier production function models. Journal of Econometrics, 6(1), 21-37. 
http://dx.doi.org/10.1016/0304-4076(77)90052-5

Ajibefun, I. A. (2003). Determinants of technical efficiency in traditional agricultural production: application of stochastic frontier modelling to food crop farmers in South-Western Nigeria. African Journal of Economic Policy, 10(2), 31-56.

Alene, D. A., Manyong, V. M., \& Gockowski, J. (2006). The production efficiency of intercropping annual and perennial crops in southern Ethiopia: A comparison of distance functions and production frontiers. Agricultural systems, 91(2006), 51-70. http://dx.doi.org/10.1016/j.agsy.2006.01.007

Ali, F., Parikh, A., \& Shah, M. K. (1996). Measurement of economic efficiency using the behavioural and stochastic cost frontier approach. Journal of Policy Modelling, 18(3), 271-287. http://dx.doi.org/10.1016/0161-8938(95)00142-5

Ali, M., \& Flinn, J. C. (1989). Profit Efficiency among Basmati Rice Producers in Pakistan Punjab. American Journal of Agricultural Economics, 71(2), 303-310. http://dx.doi.org/10.2307/1241587

Alvarez, A., \& Arias, C. (2004). Technical efficiency and farm size: a conditional analysis. Agricultural Economics, 30(3), 241-250. http://dx.doi.org/10.1016/j.agecon.2003.04.001

Anthony, V. M., \& Ferroni, M. (2012). Agricultural biotechnology and smallholder farmers in developing countries. Current Opinion in Biotechnology, 23(2), 278-285. http://dx.doi.org/10.1016/j.copbio.2011.11.020

Asfaw, S., Shiferaw, B., Simtowe, F., \& Lipper L (2012). Impact of modern agricultural technologies on smallholder welfare: Evidence from Tanzania and Ethiopia. Food Policy, 37(3), 283-295. http://dx.doi.org/10.1016/j.foodpol.2012.02.013

Barrett, C. B., Bellemare, M. F., \& Hou, J. Y. (2010). Reconsidering Conventional Explanations of the Inverse Productivity-Size Relationship. World Development, 38(1), 88-97. http://dx.doi.org/10.1016/j.worlddev.2009.06.002

Battese, G. E. (1992). Frontier production functions and technical efficiency: a survey of empirical applications in agricultural economics. Agricultural Economics, 7(3-4), 185-208. http://dx.doi.org/10.1016/0169-5150(92)90049-5

Battese, G. E., \& Coelli, T. J. (1995). A model for technical inefficiency effects in a stochastic frontier production function for panel data. Empirical Economics, 20(2), 325-332. http://dx.doi.org/10.1007/BF01205442

Berger, A. N., \& Mester, L. J. (1997). Inside the black box: What explains differences in the efficiencies of financial institutions? Journal of Banking \& Finance, 21(7), 895-947. http://dx.doi.org/10.1016/S0378-4266(97)00010-1

Binam, J. N., Tonyè, J., Wandji, N., Nyambi, G., \& Akoa, M. (2004). Factors affecting the technical efficiency among smallholder farmers in the slash and burn agriculture zone of Cameroon.

Food

Policy,

29(5),

531-545. 
http://dx.doi.org/10.1016/j.foodpol.2004.07.013

Bravo-Ureta, B. E., \& Evenson, R. E. (1994). Efficiency in agricultural production: the case of peasant farmers in eastern Paraguay. Agricultural Economics, 10(1), 27-37. http://dx.doi.org/10.1016/0169-5150(94)90037-X

Chamberlin, J., Jayne, T. S., \& Heady, D. (2014). Scarcity amidst abundance? Reassessing the potential for cropland expansion in Africa. Food Policy, (2014), http://dx.doi.org/10.1016/j.foodpol.2014.05.002

Coelli, T., Rao, D. S. P., \& Battese, G. E. (1998). An Introduction to Efficiency and Productivity Analysis. Kluwer Academic, Boston.

Collier, P. (1983). Malfunctioning of African Rural Factor Markets: Theory and a Kenyan Example. Oxford Bulletin of Economics and Statistics, 45(2), 141-72. http://dx.doi.org/10.1111/j.1468-0084.1983.mp45002001.x

Cunguara, B., \& Darnhofer, I. (2011). Assessing the impact of improved agricultural technologies on household income in rural Mozambique. Food Policy, 36(3), 378-390. http://dx.doi.org/10.1016/j.foodpol.2011.03.002

Deininger, K., \& Olinto, P. (2001). Rural Nonfarm Employment and Income Diversification in Colombia. World Development, 29(3), 455-465. http://dx.doi.org/10.1016/S0305-750X(00)00106-6

Fan, S., Chan-Kang, C., Qian, K., \& Krishnaiah, K. (2005). National and international agricultural research and rural poverty: the case of rice research in India and China. $\begin{array}{lll}\text { Agricultural } \quad \text { Economics, } & 369-379 .\end{array}$ http://dx.doi.org/10.1111/j.1574-0864.2005.00077.x

Frisvold, G., \& Ingram, K. (1995). Sources of agricultural productivity growth and stagnation in sub-Saharan Africa. Agricultural Economics, 13(1), 51-61. http://dx.doi.org/10.1016/0169-5150(95)01143-9

Helfand, S. M., \& Levine, E. S. (2004). Farm size and the determinants of productive efficiency in the Brazilian Center-West. Agricultural Economics, 31(2-3), 241-249. http://dx.doi.org/10.1016/j.agecon.2004.09.021

Hyuha, T. S., Bashaasha, B., Nkonya, E., \& Kraybill, D. (2007). Analysis of profit inefficiency in rice production in Eastern and Northern Uganda. African crop Science Journal 15(4), 243-253.

Kropff, M. J., van Arendonk, J. A. M., \& Loffler, H. J. M. (eds) (2013). Food for All: Sustainable Nutrition Security. 95 Years Wageningen University.

Latruffe, L., \& Piet, L. (2014). Does land fragmentation affect farm performance? A case study from Brittany, France. Agricultural Systems, 129(0), 68-80. http://dx.doi.org/10.1016/j.agsy.2014.05.005

Manjunatha, A. V., Anik, A. R., Speelman, S., \& Nuppenau, E. A. (2013). Impact of land 
fragmentation, farm size, land ownership and crop diversity on profit and efficiency of irrigated farms in India. Land Use Policy, 31(0), 397-405. http://dx.doi.org/10.1016/j.landusepol.2012.08.005

Meeusen, W., Broeck, J. van D. (1977). Efficiency Estimation from Cobb-Douglas Production Functions with Composed Error. International Economic Review, 18(2), 435-444. http://dx.doi.org/10.2307/2525757

Nin-Pratt, A., \& McBride, L. (2014). Agricultural intensification in Ghana: Evaluating the optimist's case for a Green Revolution. Food Policy, (2014). http://dx.doi.org/10.1016/j.foodpol.2014.05.004

Ofori-Bah, A., \& Asafu-Adjaye, J. (2011). Scope economies and technical efficiency of cocoa agroforesty systems in Ghana. Ecological Economics, 70(8), 1508-1518. http://dx.doi.org/10.1016/j.ecolecon.2011.03.013

Ojo, S. O. (2004). Improving Labour productivity and Technical efficiency in food cropproduction: A panacea for poverty Reduction in Nigeria. Food, Agriculture and Environment, 2(2), 227-231.

Pender, J., Nkonya, E., Jagger, P., Sserunkuuma, D., \& Ssali, H. (2004). Strategies to increase agricultural productivity and reduce land degradation: evidence from Uganda. $\begin{array}{lll}\text { Agricultural } \quad \text { Economics, } & \text { 31(2-3), } & \text { 181-195. }\end{array}$ http://dx.doi.org/10.1016/j.agecon.2004.09.006

Quisumbing, A. R. (1996). Male-female differences in agricultural productivity: Methodological issues and empirical evidence. World Development, 24(10), 1579-1595. http://dx.doi.org/10.1016/0305-750X(96)00059-9

Rahman, S. (2003). Profit efficiency among Bangladeshi rice farmers. Food Policy, 28(5-6): 487-503. http://dx.doi.org/10.1016/j.foodpol.2003.10.001

Raphael, I. O. (2008). Technical efficiency of cassava farmers in south eastern Nigeria: Stochastic frontier approach. Agricultural Journal, 3(2), 152-156.

Rehman, T. (1982). Technical and economic criteria in agricultural production: A case for a systems approach to farm decision-making in the Pakistan Punjab. Agricultural Systems, 9(1), 43-55. http://dx.doi.org/10.1016/0308-521X(82)90039-7

Renkow, M., \& Byerlee, D. (2010). The impacts of CGIAR research: A review of recent evidence. Food Policy, 35(5), 391-402. http://dx.doi.org/10.1016/j.foodpol.2010.04.006

Sienso, G., Asuming-Brempong, S., \& Amegashie, D. P. K. (2014). Estimating the efficiency of maize farmers in Ghana. Asian Journal of Agricultural Extension, Economics and Sociology, Article no. AJAEES 2014.6.021

SRID, (2010). Ghana Food and Balance Sheet (2009/2010) report, p.14

Tsionas, E. G., \& Kumbhakar, S. C. (2004). Markov switching stochastic frontier model. Econometrics Journal, $7(2)$, $398-425$. 
http://dx.doi.org/10.1111/j.1368-423X.2004.00137.x

Udry, C., Hoddinott, J., Alderman, H., \& Haddad, L. (1995). Gender differentials in farm productivity: implications for household efficiency and agricultural policy. Food Policy, 20(5), 407-423. http://dx.doi.org/10.1016/0306-9192(95)00035-D

WDR, (2008). World Development Report 2008: Agriculture for Development. The World Bank, Washington, DC.

Xu, Z., Guan, Z., Jayne, T. S., \& Black, R. (2009). Factors influencing the profitability of fertilizer use on maize in Zambia. Agricultural Economics, 40(4), 437-446. http://dx.doi.org/10.1111/j.1574-0862.2009.00384.x

\section{Copyright Disclaimer}

Copyright for this article is retained by the author(s), with first publication rights granted to the journal.

This is an open-access article distributed under the terms and conditions of the Creative Commons Attribution license (http://creativecommons.org/licenses/by/3.0/). 